\title{
Screening of Earthworm (Eudrilus eugeniae) Gut as a Transient Microbial Habitat
}

\author{
Sruthy.P.B ${ }^{1, *}$, Anjana.J.C ${ }^{1}$ J. Rathinamala ${ }^{1}$, S. Jayashree ${ }^{2}$ \\ ${ }^{1}$ Department of Microbiology, Nehru Arts and Science College, Affiliated to Bharathiar University, Coimbatore, India \\ ${ }^{2}$ Department of Biotechnology, Nehru Arts and Science College, Affiliated to Bharathiar University, Coimbatore, India \\ *Corresponding Author: speedysru@gmail.com
}

Copyright (C) 2013 Horizon Research Publishing. All rights reserved.

\begin{abstract}
Earthworms are soil invertebrates which play a major role in recycling organic matter in soils. The unique microenvironment of the earthworm gut impacts on the catabolic activities of ingested soil microorganisms. The ingested microbial populations play an important role in earthworm nutrition by helping in the breakdown of organic matter. A study was carried out to find out the distribution of microorganisms in the gut of earthworm, Eudrilus eugeniae. The vermibeds were prepared with cow dung and pre-decomposed banyan leaf litter. The population of bacteria, fungi and actinomycetes were determined in the gut regions (foregut, midgut and hindgut) of earthworm $E$. eugeniae. The predominant microorganisms found in the foregut, midgut and hindgut were bacteria, actinomycetes and fungi respectively. It was observed that there are variations in the population of microorganisms in the foregut, midgut and hindgut. This report shows the distribution of various microorganisms in the gut regions and how it favors the animal to have a healthy life in the environment.
\end{abstract}

Keywords Invertebrates, Gut, Eudrilus engeniae, Leaf litter, Vermibeds

\section{Introduction}

The intestine of the worm contains microorganisms and gut enzymes. The microflora in the intestine of earthworm decomposes these triturated and particulated particles [1]. The number of organisms in the cast is more than the surrounding soil [2]. Recent studies by Reference [3] have shown the occurrence of a variety of species of microorganisms in the gut of earthworms. The diversity of types and number of fungi, bacteria, actinomycetes, yeast and protozoa in the gut and casts of L. mauritii, E. eugeniae, E. fetida and $P$. excavates fed on different substrates were reported by many of the researchers. Similar to the occurrence of greater number of microbes in the gut of earthworms, the cast also contains more microorganisms.
However, qualitative and quantitative surveys of microbial flora of various earthworms are still warranted. Biocomposting of solid wastes bring about stabilization of the organic matter and effectively reduces pathogen concentrations in sludge's to very low levels. The absolute removal of pathogens becomes difficult to achieve and many survives the composting process [4].

\section{Materials and Methods}

\subsection{Selection of Suitable Species}

Selection of suitable species for vermiculturing was done according to the requirement, for composting, poultry and animal feed. In general, some species are 'vermicultured' that have other possible commercial utilization like Eudrilus eugeniae (Figure 1).

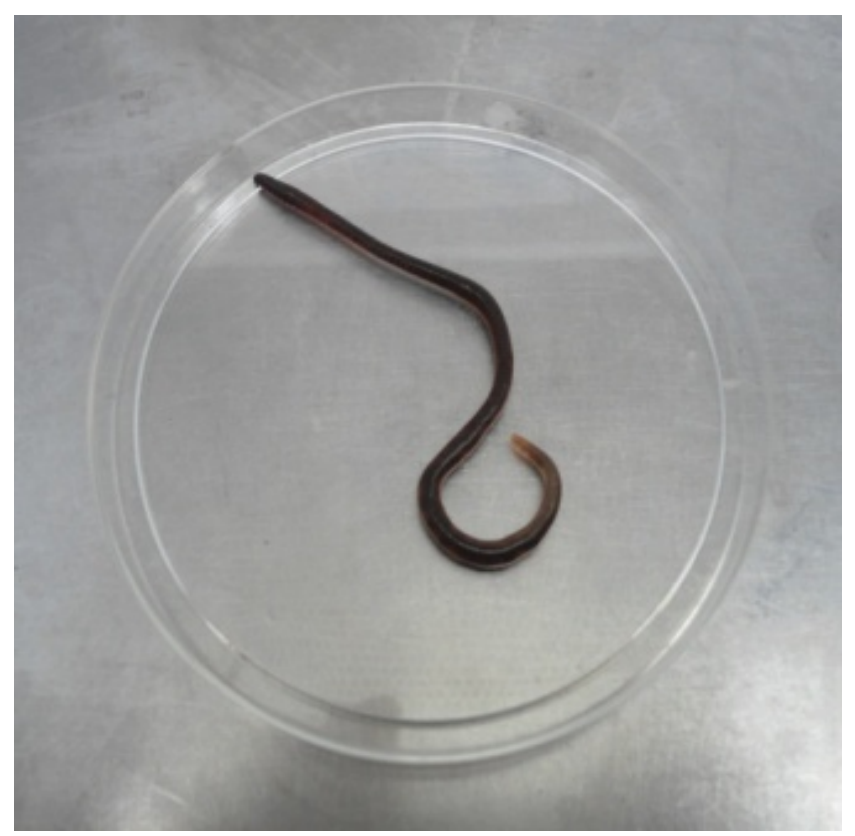

Figure 1. Eudrilus eugeniae 


\subsection{Earthworm Culture}

E. eugeniae were collected from the Vermiculturing Unit maintained by the Department of Biosciences, NASC, Coimbatore, brought to the laboratory and mass cultured in a culture tank $(1 \mathrm{~m} \times 1 \mathrm{~m} \times 1 \mathrm{~m})$ containing urine free cow dung. Cow dung was collected from nearby cattle shed, sun dried and powdered. Worms were acclimatized in cow dung and used for various experimental studies (Figure $2 \& 3$ ).

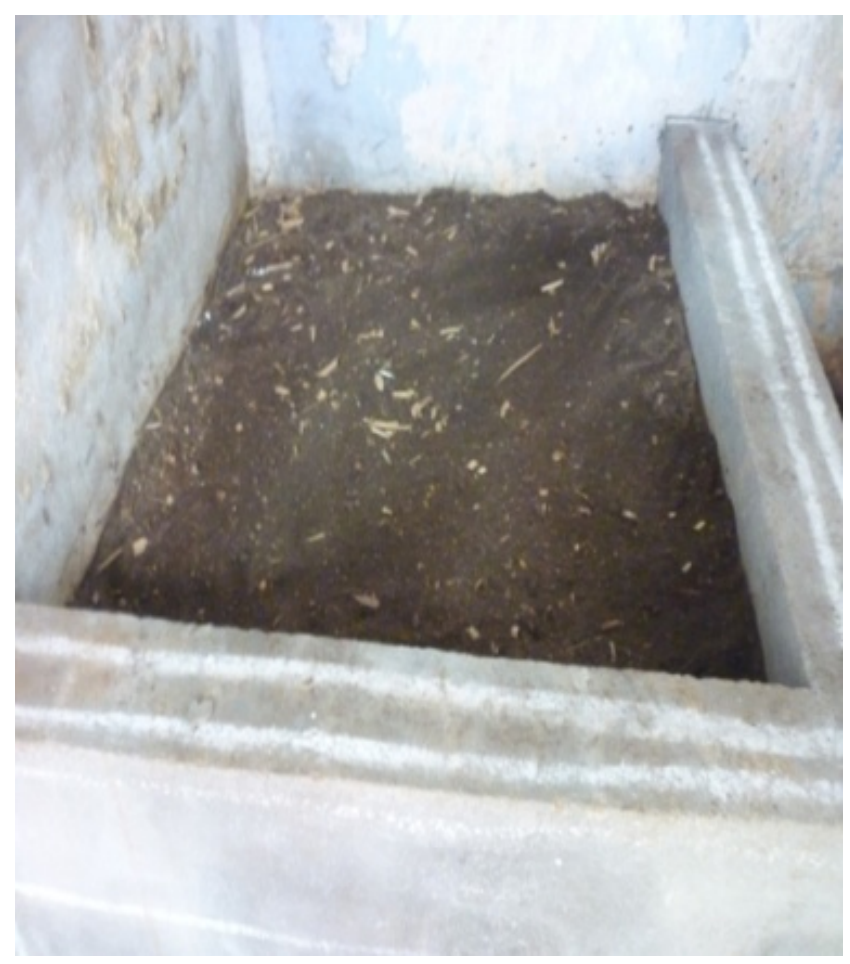

Figure 2. Vermiculture Tank

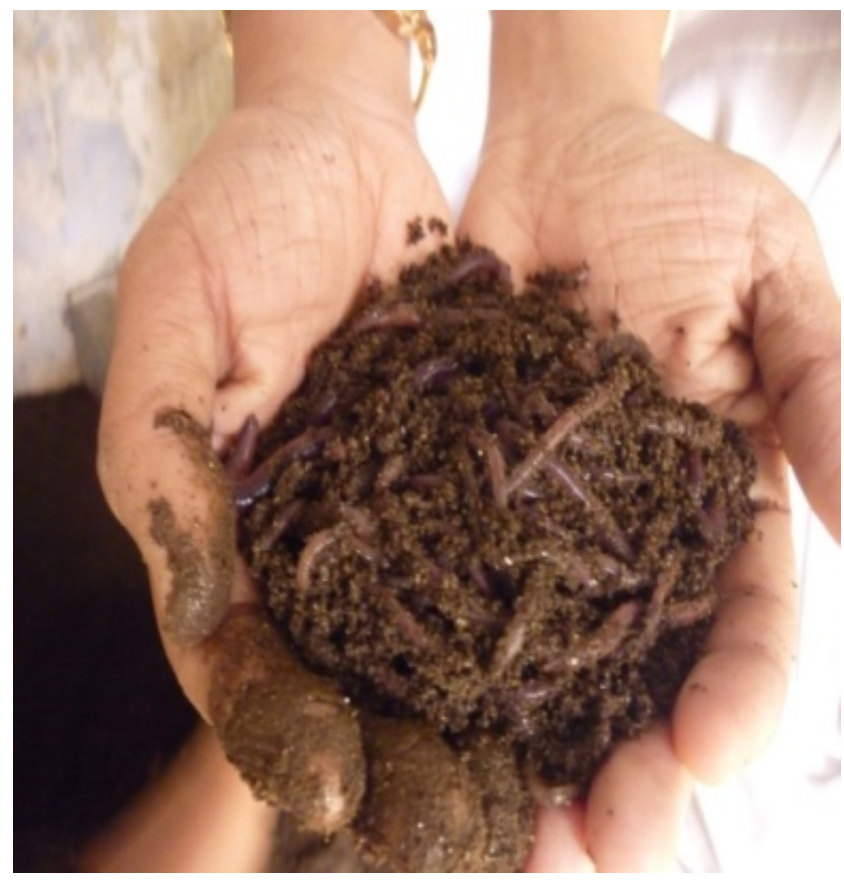

Figure 3. Inoculation of Worms in the culture Tank

\subsection{Vermibed Preparation}

The pre-decomposed waste materials from the plastic tubes were taken for the vermibed preparation. The vermibeds were prepared with cow dung and pre-decomposed banyan leaf litter $(\mathrm{CD}$ and $\mathrm{BL})$ in the ratio of $1: 1$ in plastic containers of $15 \mathrm{~cm} \times 15 \mathrm{~cm} \times 12 \mathrm{~cm}$ size. Water was sprinkled over the vermibeds to hold the moisture content of $60 \%$ to $70 \%$ and kept for 24 hours. Ten healthy, matured E. engeniae of 10 to $12 \mathrm{~cm}$ length and 0.4 to $0.8 \mathrm{~g}$ weight were taken from the culture tank and were introduced in to the plastic containers. The containers were covered with perforated lids for ventilation and for the prevention of predators (Figure 4).

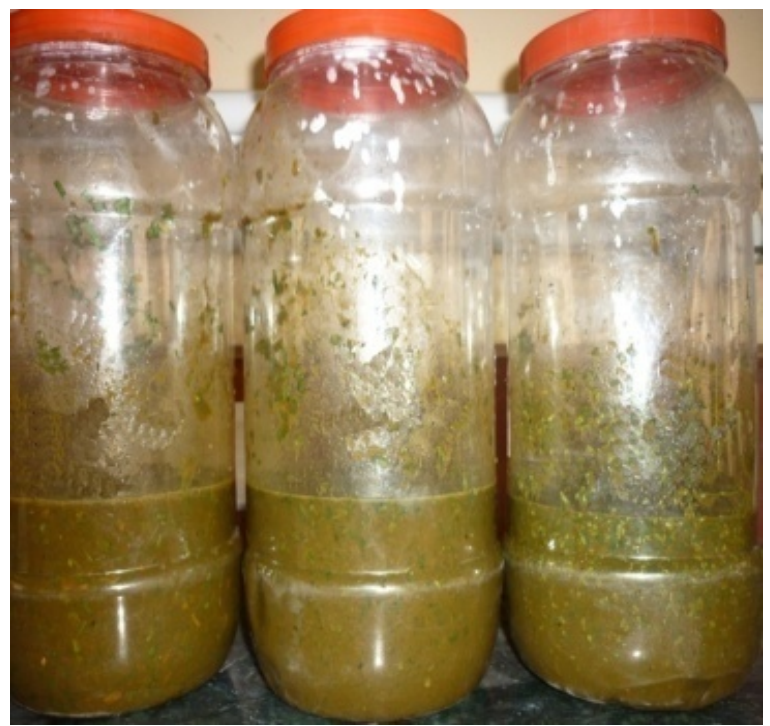

(CD: BL in 1:1 ratio)

Figure 4. Vermibed Preparation in plastic containers

\subsection{Enumeration of Microbes}

A healthy worm was selected for enumeration of microbes by pour plate method. It was dissected to three regions as foregut, midgut and hindgut. The serial dilutions were performed for each gut sections and were individually plated on to Nutrient agar, Actinomycetes isolation agar and Sabouraud's dextrose agar for bacteria, actinomycetes and fungi respectively. Enumeration process was carried out at regular intervals up to 60th day.

\section{Results}

It was found that there was a gradual increase in their population from the initial day to final day. The maximum Bacterial population was found in the foregut region than in midgut and hindgut region. The fungal population was maximum in the hindgut region. The next highest population was noted in the foregut. Actinomycetes population was predominant in the midgut than foregut and hindgut (Table 1, Figure 5, $6 \& 7$ ). 
Table 1. Microbial Population in the Gut of E. Eugeniae during the process of Vermicomposting

\begin{tabular}{|c|c|c|c|c|c|c|c|c|c|c|c|c|c|c|c|}
\hline \multirow{2}{*}{ Micro Organisms } & \multicolumn{5}{|c|}{$\begin{array}{c}\text { Foregut } \\
\left(10^{5} \times \mathrm{cfu} / \mathrm{g}\right)\end{array}$} & \multicolumn{5}{|c|}{$\begin{array}{c}\text { Midgut } \\
\left(10^{5} \times \mathrm{cfu} / \mathrm{g}\right)\end{array}$} & \multicolumn{5}{|c|}{$\begin{array}{l}\text { Hindgut } \\
\left(10^{5} \times \mathrm{cfu} / \mathrm{g}\right)\end{array}$} \\
\hline & 0 & 15 & 30 & 45 & 60 & 0 & 15 & 30 & 45 & 60 & 0 & 15 & 30 & 45 & 60 \\
\hline Bacteria & $12 *$ & $50 *$ & $76^{*}$ & $90^{*}$ & $136^{*}$ & 30 & 41 & 52 & 55 & 80 & 43 & 52 & 65 & 81 & 96 \\
\hline Actinomycetes & 7 & 7 & 8 & 11 & 22 & $12 *$ & $14^{*}$ & $16^{*}$ & $18^{*}$ & $30^{*}$ & 10 & 9 & 6 & 9 & 14 \\
\hline Fungi & 15 & 18 & 25 & 25 & 32 & 11 & 17 & 20 & 23 & 31 & $19 *$ & $22 *$ & $31 *$ & $32 *$ & $43 *$ \\
\hline
\end{tabular}

$* \mathrm{p}<0.05(\mathrm{n}=3)$
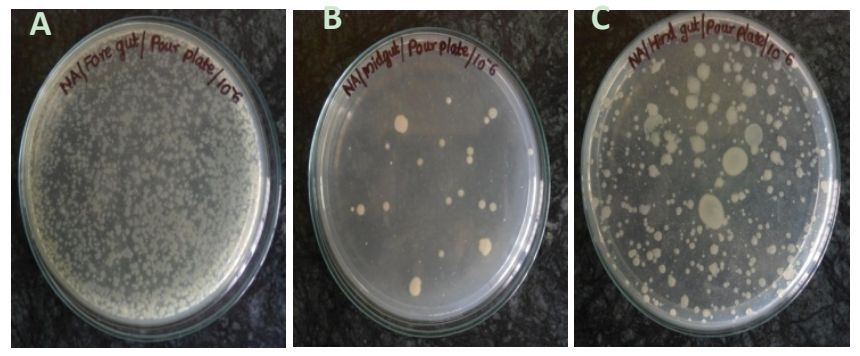

Figure 5. Bacteria: Foregut (A), Midgut (B) and Hindgut (C)
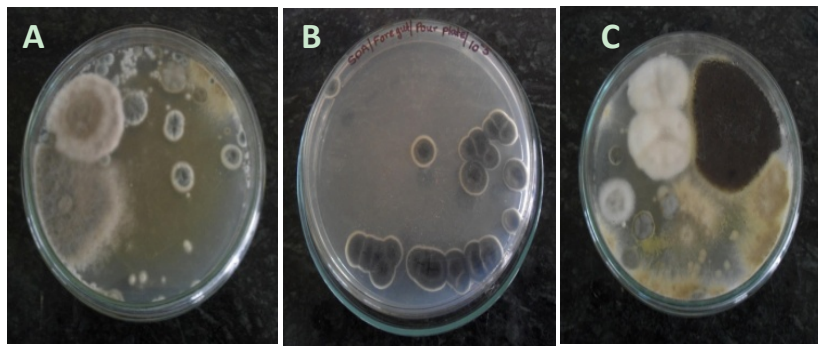

Figure 6. Fungi: Foregut (A), Midgut (B) and Hindgut (C)
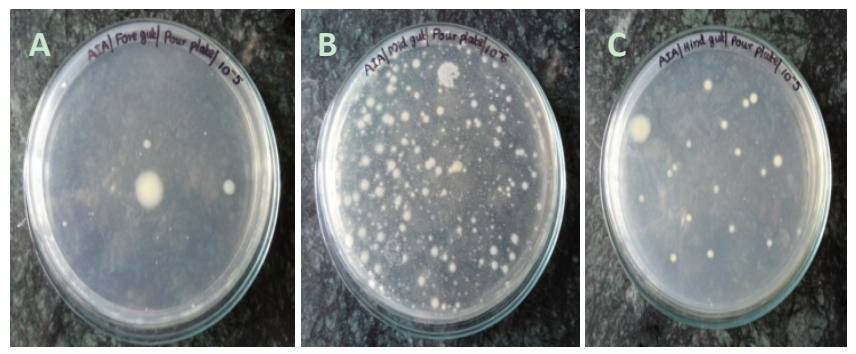

Figure 7. Actinomycetes: Foregut (A), Midgut (B) and Hindgut (C)

\section{Discussion}

In the present study, a significant number of microbial populations in the gut of earthworm were observed. It was increased from the initial day to final day of vermicomposting. Earthworms, for their growth and reproduction, have been shown to meet their nutritional requirement by feeding on organic matter and microbes [5]. Microorganisms constitute an important nutritional component of the earthworm diet [6]. Earthworms have been shown to be microbivorous [7-8]. The ingestion of microorganisms by earthworms is reported by a few authors but there is no agreed opinion as to what type of microorganism is eaten and digested by earthworms. Earthworm was shown to have minimal capacity to digest organic residues and obtain nutrition by digestion of microorganisms associated with ingested organic matter [9].

Differences in earthworm digestion and assimilation processes suggest the possible existence of ecological group-specific gut microbiota [10]. Although the microbial profile of the gut content is akin to that of soil and feed resources [11-14], it is not a coincidal combination of the microorganisms in soil [15]. Increase in microbial populations might be due to the environmental conditions 
prevailing and nutritional status in the gut of earthworm as reported by References [16-18]. It was observed that there are variations in the population of microorganisms in the foregut, midgut and hindgut of earthworm. The first documented studies on the effects of earthworms on microorganisms were those of Reference [19]. He isolated more than 60 species of microorganisms (less than 50 of them bacteria) from $L$. terrestris casts and gut contents.

\section{Conclusion}

The gut of the earthworm constitutes a unique microenvironment in soils. The selective digestion of microbes in the gut influences the type of nutrients that are available for subsequent assimilation by both the earthworm and members of the gut microflora. The variation in the microbial populations in the earthworm gut may be because of their nutritional needs and digesting ability of the earthworms. Indeed, the survival of microorganisms in the earthworm gut depends on their capacity to resist to digestive enzymes of microbial or earthworm origins, intestinal mucus, $\mathrm{CaCO}_{3}$, or to bacteriostatic and microbial substances. The bacteria in the foregut helps to digest the food particles, actinomycetes in the midgut helps to destroy the pathogens by antagonistic activity, and the fungi help to bind the waste particles as castings in the hindgut. We look forward to future studies aimed at understanding the importance of this microniche.

\section{REFERENCES}

[1] P. C. Mishra, M. C. Dash. Digestive enzymes in some earthworms. Experien - tic., Vol. 36, No. 10, 1156 - 57, 1980.

[2] J. E. Satchell. Earthworm microbiology, In: Earthworm ecology from Darwin to vermiculture, J. E. Satchell (eds) London; Chapman and Hall, pp 351 - 364, 1983.

[3] K. Parthasarathi, L. S. Ranganathan, V. Anandhi, J. Zeyer. Diversity of microflora in the gut and casts of tropical composting earthworms reared on different substrates. J. Environmental Biology, Vol. 28, No. 12. 2006.

[4] J. R. Sidhu, A. Gibbs, G. E. Ho, I. Unkovich. The role of indigenous microorganisms in suppression of Salmonella regrowth in composted biosolids, Water Research, Vol. 35, $913-920,2001$.

[5] K. Parthasarathi, L. S. Ranganathan. Influence of pressmud on the development of the ovary, oogenesis and the neurosecretory cells of the earthworm, Eudrilus eugeniae (Kinberg). African Zool., Vol. 35, No. 2, 281-286, 2000.

[6] C. A. Edwards, P. J. Bohlen. Biology and ecology of earthworms. 3rd Edn., Chapman and Hall, London, 1996.

[7] F. M. Flack, R. Hartenstein. Growth of the earthworm Eisenia fetida on microorganisms and cellulose. Soil Biol. Biochem., Volume 16, 491-495, 1984.

[8] L. S. Ranganathan, K. Parthasarathi. Precocious development of Lampito mauritii and Eudrilus eugeniae reared in pressmud. Pedobiologia. Volume 43, 904-908, 1999.

[9] P. C. Lavelle, D. Trigo. Lattaud, I. Barois. Mutualism and biodiversity in soils In: The significance and regulation of soil biodiversity (Eds: H.P. Collins, G.P. Robertson and M.J. Klug). Kluwer Academic Publisher, Netherland, 23-33, 1995.

[10] P. Lavelle, A.V. Spain. Soil ecology. Kluwer Academic Publishers, Dordrecht., pp.654, 2001.

[11] M. S. Egert, B. Marhan Wagner, S. Scheu, M. W. Friedrich. Molecular profiling of 16S rRNA genes reveals diet-related differences of microbial communities in soil, gut and casts of Lumbricus terrestris L. (Oligochaeta: Lumbricidae), FEMS Microb Ecol., Vol. 48, 187- 197, 2004.

[12] H. L. Drake, M. A. Horn. As the worm turns: the earthworm gut as a transient habitat for soil microbial biomes, Annu Rev Microbiol., Vol. 61, 169-189, 2007.

[13] B. A. Knapp, J. Seeber, S. M. Podmirseg, E. Meyer, H. Insam. Application of denaturing gradient gel electrophoresis for analyzing the gut microflora of Lumbricus rubellus Hoffmeister under different feeding conditions, Bull Entomol Res., Vol. 98, 271-279, 2008.

[14] B. A Knapp, S. M. Podmirseg, J. Seeber, E. Meyer, H. Insam. Diet-related composition of the gut microbiota of Lumbricus rubellus as revealed by a molecular finger printing technique and cloning, Soil Biol. Biochem., Vol. 41, 2299-2307, 2009.

[15] L. Sampedro, J. K. Whalen. Changes in the fatty acid profiles through the digestive tract of the earthworm Lumbricus terrestris L, Appl Soil Ecol., Vol. 35, 226-236. 2007.

[16] B. K. Senapati, C. M. Dash. Functional role of earthworms in the decomposer subsystem, Tropical ecology, Vol. 25, $52-$ 72,1984

[17] I. S. Thorpe, K. Killham, J. Prosser, L. A. Glover. Novel method for the study of the population dynamics of a genetically modified microorganism in the gut of the earthworm Lumbricus terrestris, Biology and Fertility of Soils, Vol. 15, 55 - 99, 1993.

[18] C. A. Edwards, P. J. Bohlen. Biology and Ecology of Earthworms. 3rd. Chapman and Hall, London, 1996.

[19] K. Bassalik. On silicate decomposition by soil bacteria, Z. Garungs - Physiol., Vol. 2, 1- 2, 1913. 